\title{
Improving Student's Factual Knowledge with Concrete Media through Observing Activities in Scientific Approaches in Elementary Schools
}

\section{Wayan Widiana ${ }^{1 \rtimes}$ \\ I Made Tegeh ${ }^{2}$ \\ I Gusti Lanang Agung Parwata ${ }^{3}$ Hanikah $^{4}$}

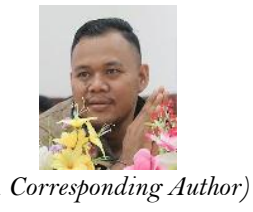

( Corresponding Author)

${ }_{1,2, s}$ Universitas Pendidikan Ganesha, Indonesia.

Email:wayan_widiana@yahoo.co.id

${ }^{4}$ Universitas Muhammadiyah Cirebon, Indonesia.

\begin{abstract}
The current conditions in Indonesia show that student activities in the learning process tend to be passive which impacts factual knowledge. This study aims to analyze the effectiveness of concrete media in improving students' factual knowledge through observing activities. This study was quasi-experimental, designed in a non-equivalent post with only a control group. The population examined where the 4th-grade elementary school students in the 2013 curriculum pioneer school, Buleleng Regency. A total of 353 students were randomly sampled, and a group of 56 students was identified to take part. Data were collected on students' factual knowledge using objective tests. Data were analyzed using descriptive statistics, namely modus, median, mean, and inferential statistics, i.e., the t-test. The results of the t-test analysis with $t$-count were greater than the t-table, $5.46>2.00$. Thus, it can be concluded that observing learning activities assisted by concrete media has a positive effect on students' factual knowledge in an elementary school. This finding will have implications that will lead to an increase in the factual knowledge of students in elementary schools by using concrete media through observing activities.
\end{abstract}

Keywords: Factual knowledge, Observing, Concrete media, Scientific approach.

Citation | I Wayan Widiana; I Made Tegeh; I Gusti Lanang Agung Parwata; Hanikah (2020). Improving Student's Factual Knowledge with Concrete Media through Observing Activities in Scientific Approaches in Elementary Schools. Journal of Education and eLearning Research, 7(3): 293-299.

History:

Received: 4 June 2020

Revised: 8 July 2020

Accepted: 12 August 2020

Published: 31 August 2000

Licensed: This work is licensed under a Creative Commons

Attribution 3.0 License (oc)

Publisher: Asian Online Journal Publishing Group
Acknowledgement: All authors contributed to the conception and design of the study.

Funding: This study received no specific financial support.

Competing Interests: The authors declare that they have no conflict of interests.

Transparency: The authors confirm that the manuscript is an honest, accurate, and transparent account of the study was reported; that no vital features of the study have been omitted; and that any discrepancies from the study as planned have been explained.

Ethical: This study follows all ethical practices during writing.

\section{Contents}

1. Introduction

2. Method...

3. Results and Discussion

4. Discussion

296

5. Conclusion

References 


\section{Contribution of this paper to the literature}

This study contributes to the existing literature by analyzing the effectiveness of concrete media in improving students' factual knowledge through observing activities.

\section{Introduction}

Education in Indonesia has been affected several times by curriculum changes and improvements. A series of improvements based on competency was pioneered in 2004, then continued in 2006, and implemented in the 2013 curriculum (KTSP). The 2013 curriculum is expected to be able to guide students to find things out, not be told, so that an active, creative, and innovative generation is formed who are trained in problem-solving so they can manage the social changes occurring in the surrounding environment (Asrizal, Amran, Ananda, Festiyed, \& Sumarmin, 2018; Usmeldi, 2016). The 2013 curriculum assessment must be able to balance affective, cognitive, and psychomotor abilities (Jayanta, Suryantari, \& Sumantri, 2017; Retnawati, Hadi, \& Nugraha, 2016).

The 2013 curriculum has been implemented in selected pilot schools for three years. The government hopes that the 2013 curriculum can improve the quality of learning activities in schools and make them more active and meaningful for students so that student learning outcomes will improve. Based on observations at the 2013 curriculum pilot school in the Buleleng district, during the three years of the 2013 curriculum learning process, the implementation of the five scientific approach steps involved no innovation or development in its learning activities. It seems as though the 2013 curriculum learning activities look similar to the SBC learning activities. So, it is necessary to develop learning activities in different directions. This finding is supported by the results of the study where (Widyani, Suwatra, \& Widiana, 2017) also found similar obstacles in the implementation of the 2013 curriculum, namely the lack of availability of selected learning media. This is consistent with what was stated by Antara and Renda (2016) through observations and interviews conducted in elementary schools in Banyuasri, Bali. Teachers felt there were obstacles to the application of learning with the 2013 curriculum, and the teachers still could not adapt to the system because it was new, so it had not been implemented optimally.

The following data was returned based on the results of observations made by researchers of the average value of the test results on theme 5 in fourth-grade students in the 2013 curriculum pioneer elementary school in Buleleng. The average value of the test results on theme 5 in fourth-grade students of the 2013 pioneer curriculum elementary school in Buleleng can be seen in Table 1.

\begin{tabular}{|c|c|c|c|c|}
\hline School identity & Class & Total students & Average of test results & Standard value \\
\hline \multirow[t]{2}{*}{ Elementary School of Laboratorium Undiksha } & IVA & 37 & 70,81 & \multirow[t]{2}{*}{75} \\
\hline & IVB & 37 & 69,59 & \\
\hline \multirow[t]{3}{*}{ Elementary School of 3 Banjar Jawa } & IVA & 32 & 70 & \multirow[t]{3}{*}{75} \\
\hline & IVB & 31 & 70,96 & \\
\hline & IVC & 31 & 70,80 & \\
\hline \multirow[t]{2}{*}{ Elementary School of 4 Kampung Baru } & IVA & 25 & 68,6 & \multirow[t]{2}{*}{70} \\
\hline & IVB & 21 & 68,80 & \\
\hline Elementary School of 1 Busungbiu & IV & 39 & 68,33 & 70 \\
\hline Elementary School of 4 Kaliuntu & IV & 39 & 69.10 & 70 \\
\hline Elementary School of 4 Banyuasri & IV & 36 & 68,75 & 70 \\
\hline Elementary School of 6 Pejarakan & IV & 25 & 68 & 70 \\
\hline
\end{tabular}

Source: Observation data of grade IV of the 2013 pioneer curriculum elementary school in Buleleng.

Based on Table 1 above, it can be seen that the average grade of grade IV students in the seven elementary schools pioneering the 2013 curriculum of the Buleleng Regency is still below the established standards. The low average shows that the factual knowledge of students is low. Based on Revised Blom's Taxonomy Theory, the dimensions of knowledge are categorized into four dimensions, one of which is factual knowledge. Factual knowledge is knowledge of separate elements and concerning pieces of information. It is divided into two subtypes, namely knowledge of terminology and knowledge of specific details and elements (Astiti, Suniasih, \& Wiarta, 2015; Esposito \& Bauer, 2017; Kapler, Weston, \& Wiseheart, 2015).

Based on the results of interviews with teachers, it can be seen that the factors causing low factual knowledge, including limited use of media, are related to teachers being reluctant to use learning media because they assume it will require much preparation. Consequently, teachers are less able to operate and associate media with learning material. Additionally, students are less able to express what is being observed, while the teacher is less active at facilitating students, such as inviting students to observe directly. Therefore, students are less able to express what is being observed.

Based on the explanation of the above problems, it is known that the ongoing learning process is not able to foster interest, the fulfillment of students' curiosity, sincerity, accuracy in seeking information, and student activity in participating in learning, especially the students observing activities. Student learning will be carried out using a scientific approach. A scientific approach aims to obtain systematic scientific knowledge (Cannady, Vincent-Ruz, Chung, \& Schunn, 2019; Hernawati, Amin, Irawati, Indriwati, \& Omar, 2018; Syahroni, Dewi, \& Kasmui, 2016; Triyuni, 2016). The first step in the scientific learning process is observing. This activity aims to obtain a general description of a material object regarding the basic competencies to be studied.

Observing is one of the significant contributing factors for students' success in learning, as a teacher should be able to provide opportunities and encourage students to be active in learning, especially when it comes to asking questions. Students observe through activities: seeing, listening, and reading are formulated in the learning process scenario (Jampel \& Puspita, 2017). One of the efforts that can be made to encourage and increase the activeness of students in observing is by applying innovations from concrete media because elementary school children are still at the stage of concrete operational development. Learning activities for elementary school children require media that can facilitate learning so that learning objectives can be achieved. Learning media also play a role in 
optimizing the learning process, and the use of instructional media can create interesting learning and make it easier for students to understand the material presented (Dwipayanti, Sudhita, \& Parmiti, 2013). Therefore, learning a concept requires experience through tangible (concrete) objects, namely learning media that can be used as a bridge for students to think abstractly (Dirk, Deprez, Van Dooren, Roelens, \& Verschaffel, 2011; Moreira, Pereira, \& Gusmão, 2018; Stull, Barrett, \& Hegarty, 2013).

The concrete media in this study is the activity of learning applied by using real objects in the environment. The media are the actual objects of the material being studied. The concrete media used on theme 9 is "Kayanya Negeriku," a miniature waterwheel with a simple electric circuit which teaches real behavior about the to the importance of the environment related to non-renewable energy sources (pertalite, gasoline, diesel, iron, copper, tin, stone, aluminum) and renewable energy sources (water, land, paper, and plants). The aim is to teach real energy-saving behavior and real rights and obligations towards the natural resources of batteries, solar, electric bells, flashlights, canned telephones, windmills, taxpayer receipts, irons, fans, cars, solar-powered flashlights, bells, real behavior about human rights and obligations towards natural resources. The use of concrete media is very helpful if used in the process of obtaining information to gain knowledge through one's own or direct experience (Castela, Da Fonseca, Duarte, Neves, \& Montemor, 2014; Santiani, Sudana, \& Tastra, 2017).

To date, there have been many studies on the use of concrete media in learning. Research conducted by Santiani et al. (2017) states that concrete media influences the learning outcomes of science. The research conducted by Wardani, Made, and Mahadewi (2016) states that concrete media affects student mathematics learning outcomes. Research conducted by Darmadi, Sulastri, and Rai (2013) states that the use of concrete media in learning can have a positive and significant effect on student learning outcomes in natural sciences.

By using concrete media, students find it easier to understand the learning process as it provides real experiences and generates questions or ideas. Using concrete media invites students to observe directly the object being studied, which will later improve student learning outcomes, especially on factual knowledge. In learning with a scientific approach, innovative media-assisted learning activity innovations will be applied at the observing stage. Observing in a scientific way is when students are trained to use the five senses to obtain information (Fischer, Rotter, Schubert, Marx-Stoelting, \& Solecki, 2020; Schürmann, Ernst, Schumann, \& Hake, 2019). Through observing activities, students develop curiosity. The more trained in observing, the more curiosity can be developed, so that students will get more meaningful knowledge, which can influence their factual knowledge. The purpose of this study was to determine the effect of concrete media through observing activities in a scientific approach in elementary schools to increase factual knowledge.

\section{Method}

This research was a quasi-experimental study (quasi-experiment). The research design of the study was the non-equivalent post-test only control group design. The population in this study was grade IV elementary school students in the 2013 curriculum pioneer school in Buleleng, Bali, which totaled 353 students. The population was tested for equality to determine the research sample. The sample selection was conducted by a lottery using a random sampling technique. The sample in this study was fourth grade in 4 Kampung Baru elementary school, with 3 Banjar Jawa elementary school as the control class. Two variables were involved in this research, namely the learning activity of observing aided by concrete media, and the learning activity of observing not assisted by concrete media as an independent variable, also using factual knowledge as a dependent variable.

Data collection methods used in this study were test methods. The test method was used to obtain data on students' factual knowledge on the theme of "Kayanya Negeriku." This was an objective test used to test the truth of the research hypothesis and given after the treatment in the experimental and control classes. The research instrument used to collect data on students' factual knowledge was arranged based on the constructed grid. Before being used to retrieve data, the instruments were tested to determine the validity, reliability, and level of difficulty of the test, together with various power levels. The factual knowledge data analysis used the test before the data analysis was carried out, the prerequisite analysis was tested, namely the test data normality, and the variance homogeneity test. To test the normality of the data distribution with the Chi-Square test, the homogeneity test of variance used the F test. Microsoft Office Excel 2007 was used to process data analysis. To determine the high and low quality of these variables, the average score (mean) of each variable was converted with ideal average criteria (Mi) and the ideal standard deviation (SDi). The rating scale or category on the rating scale can be seen in Table 2.

\begin{tabular}{l|c}
\multicolumn{2}{c}{ Table-2. Rating scale or category. } \\
\hline Range of scores & Category \\
\hline $\mathrm{M}_{\mathrm{i}}+1,5 \mathrm{SD}_{\mathrm{i}} \leq \mathrm{M} \leq \mathrm{M}_{\mathrm{i}}+3,0 \mathrm{SD}_{\mathrm{i}}$ & Very good \\
\hline $\mathrm{M}_{\mathrm{i}}+0,5 \mathrm{SDi} \leq \mathrm{M}<\mathrm{Mi}^{2}+1,5 \mathrm{SD}_{\mathrm{i}}$ & Good \\
\hline $\mathrm{M}_{\mathrm{i}}-0,5 \mathrm{SDi} \leq \mathrm{M}<\mathrm{M}_{\mathrm{i}}+0,5 \mathrm{SD}_{\mathrm{i}}$ & Enough \\
\hline $\mathrm{M}_{\mathrm{i}}-1,5 \mathrm{SD}_{\mathrm{i}} \leq \mathrm{M}<\mathrm{M}_{\mathrm{i}}-0,5 \mathrm{SD}_{\mathrm{i}}$ & Not good \\
\hline $\mathrm{M}_{\mathrm{i}}-3,0 \mathrm{SD}_{\mathrm{i}} \leq \mathrm{M}<\mathrm{M}_{\mathrm{i}}-1,5 \mathrm{SD}_{\mathrm{i}}$ & Very unkind \\
\hline
\end{tabular}

\section{Results and Discussion}

\subsection{Research Result}

The data of this study are the scores of students' factual knowledge as a result of learning activities to observe concrete media aided in the experimental group and observing learning activities unaided by concrete media in the control group. Recapitulation of factual knowledge data calculations can be seen in Table 3.

Table-3. Recapitulation of data calculation results in factual knowledge results

\begin{tabular}{c|c|c|c|c|c}
\hline Group & Mean (M) & Median (Md) & Modus (Mo) & Standard Deviation & Variance \\
\hline Experiments & 21,54 & 22 & 24 & 5,27 & 27,84 \\
\hline Control & 13,80 & 12,2 & 10,4 & 5,22 & 27,29 \\
\hline
\end{tabular}


Based on Table 3, it is known that the mean data of factual knowledge of the group of students who took part in learning through learning activities assisted by concrete media was 21.54 greater than the group of students who took part in learning activities not assisted by concrete media with a mean of 13.80 . That means that the average value of factual knowledge of the experimental group students was higher than the average value of factual knowledge of the control group students. The distribution of data in the experimental group presented with the mode greater than the median, and the median greater than the mean $(\mathrm{Mo}>\mathrm{Md}>\mathrm{M})$, which means that most scores tended to be high. Conversely, the distribution of data in the control group presented with the mean greater than the median, and the median greater than mode $(\mathrm{M}>\mathrm{Md}>\mathrm{Mo})$, which means most scores tended to be low.

Based on the criteria of a scale of five, $t$ the mean learning outcomes of students in the group with learning activities observing not assisted by concrete media is 21.54 (in the very high category). Conversely, the mean of student learning outcomes in groups taught using observational learning activities not assisted by concrete media is 13.80 (in the medium category). In this study, the analysis prerequisite test was done before the hypothesis test was analyzed with the "t-test" (t-test). Before first testing the hypothesis, the analysis prerequisite test was carried out. The analysis prerequisite test consists of two things, namely (1) normality test of data distribution of the whole unit of analysis, and (2) homogeneity test of variance between groups.

The data normality test is performed on the entire unit of analysis, namely the experimental group and control group. The chi normality test for student learning outcomes uses chi-square analysis. The criteria for data are normally distributed if x2count $<$ x2table with a significance level of $5 \%(\mathrm{dk}=$ number of classes minus parameters, minus one), then Ho is accepted, which shows normally distributed data. A summary of the results of the normality test data in the experimental and control groups is presented in Table 4.

Table-4. Normality test

\begin{tabular}{l|l|c|c|c}
\hline No & Factual Knowledge Data Group & $\chi^{2}{ }_{\text {hit }}$ & $\chi_{\text {tab }}$ & Status \\
\hline 1 & Experimental Post-Test & 2,971 & 7,815 & Normal \\
\hline 2 & Control Post-Test & 7,119 & 7,815 & Normal \\
\hline
\end{tabular}

Based on the results of calculations using the chi-square, the experimental group's post-test results were 2.971 with a significance level of $5 \%$, and $\mathrm{db}=3$ was 7.815 . This means that the experimental group's post-test results were smaller $(<)$ so that the experimental group's post-test results were normally distributed. Meanwhile, the result of the control group post-test was 7.119 , with a significance level of $5 \%$, and $\mathrm{db}=3$ was 7.815 . The test used was the $\mathrm{F}$ test, which means the results of the control group post-test were smaller $(<)$, so the control group's posttest data results were normally distributed.

A homogeneity test was performed on the variance of homogeneous data criteria pairs if $\mathrm{F}_{\text {count }}<\mathrm{F}_{\text {table. }}$ A summary of the results of the homogeneity of the variance between the experimental and control groups is presented in Table 5.

\begin{tabular}{c|c|c|c|c|c|c}
\hline \multicolumn{7}{c}{ Table-5. Homogeneity test. } \\
\hline Sample & Mean & SD & Variance & F-count & F-table & Conclusion \\
\hline Experiment Class & 21,54 & 5,27 & 27,84 & 1,02 & 1,88 & F-count $<$ F-table \\
\hline Control Class & 13,80 & 5,22 & 27,29 & & & \\
\hline
\end{tabular}

Based on the table above, it is known that the $\mathrm{F} 2$ count in the experimental and control group post-test results is 1.02 , while the $\mathrm{F} 2$ table at the $\mathrm{db}$ numerator $=24$, the $\mathrm{db}$ mentioner $=30$, and a significant level of $5 \%$ is 1.88 . This means that the variance of data from the post-test results of the experimental group and the control group is homogeneous.

Based on the prerequisite test results, the factual knowledge data of the experimental and control group students were normally distributed, and the variance of the two groups was homogeneous, so the hypothesis using the t-test with the polled variance formula could be tested. The recapitulation of the results of t-test calculations between the experimental and control groups is presented in Table 6.

Table-6. Recapitulation of t-test results for experiment and control groups.

\begin{tabular}{|c|c|c|c|c|c|c|}
\hline Data & Group & $\mathbf{N}$ & $\overline{\boldsymbol{X}}$ & $\mathbf{S 2}$ & t-count & t-table (t.s.5\%) \\
\hline \multirow{2}{*}{$\begin{array}{c}\text { Factual } \\
\text { Knowledge }\end{array}$} & Experiment & 25 & 21,52 & 27,84 & \multirow[t]{2}{*}{5,46} & \multirow[t]{2}{*}{2,00} \\
\hline & Control & 31 & 13,80 & 27,29 & & \\
\hline
\end{tabular}

Based on Table 6, the results of the t-test analysis show that the t-count was greater than the table that is 5.46 $>2.00$ at a degree of freedom 54. This shows that $\mathrm{H}_{0}$ was rejected, and $\mathrm{H}_{1}$ was accepted. Thus, it can be interpreted that there is a significant difference in factual knowledge between groups of students who are taught with learning activities to observe with the help of concrete media, and groups of students who are taught with learning activities to observe unassisted by concrete media in a fourth-grade elementary school in the Buleleng Regency in the 2016/2017 academic year.

Based on the hypothesis test obtained $\mathrm{t}_{\text {-count }}=5.46$ while at a significance level of $5 \%$, and $\mathrm{dk}=54$ obtained $\mathrm{t}$. table $=2.00$ so $t_{\text {-count }}=5.46>t_{\text {-table }}=2.00$. Thus, the null hypothesis $(\mathrm{Ho})$ is rejected. This shows that there are significant differences in factual knowledge between groups of students who are taught by learning activities to observe assisted by concrete media and groups of students who are taught by learning activities to observe unassisted by concrete media in a fourth-grade elementary school in the Buleleng Regency in the 2016/2017 academic year. The theme was "Kayanya Negeriku."

\section{Discussion}

The results of this study found that there were differences in the factual knowledge of students in groups of students who were taught by learning activities to observe assisted with the help of concrete media, and groups of 
students who were taught by learning activities to observe unassisted by concrete media. Those assisted by concrete media were 21.52 higher than the average score, and the factual knowledge of students who took part in learning activities to observe unassisted by concrete media was 13,80.

Based on these findings, it can be stated that the two groups of research samples after treatment in the form of learning activities to observe assisted by concrete media and following learning activities to observe unassisted by concrete media obtained different factual knowledge of students. This can also be seen from the average of students who participated in learning activities to observe assisted with concrete media, which is higher than the average of students who took part in learning activities to observe unassisted by concrete media. In this case, it was learning that only used a scientific approach. The results presented a higher mean value in the experimental group compared with the control group.

Learning activities to observe assisted with concrete media were run optimally and effectively. This is because observing learning activities that are not assisted by concrete media is a learning innovation that encourages students' motivation to observe so that they will be able to develop their curiosity. During learning activities, students are more active because learning activities using concrete media can create a pleasant learning environment. Along with making learning more fun, using concrete media can also provide a direct or real picture of what is being learned. Concrete media is anything tangible that can be used to channel messages from the sender to the recipient to stimulate students' thoughts, feelings, concerns, and interests so that the learning process can run more effectively and efficiently in accordance with expected goals (Fischer et al., 2020; Suarjana, Riastini, \& Pustika, 2017; Susanti, Suadnyana, \& Zulaikha, 2014).

By using concrete media, students will find it easier to understand the learning process, provide real experiences, and generate questions and ideas. Thus, using concrete media invites students to observe directly the object being studied. In learning with a scientific approach, innovative learning activities assisted by real media will be applied at the observing step. While observing, students can manipulate these objects and hopefully the learning experience can be more meaningful. Besides that, it can provide direct experience to students, using models and tangible objects of an object. Learning activities can form a dynamic classroom atmosphere because the process involves the five senses being used to carefully obtain information about something.

The learning process in groups of students taught by observing learning activities assisted by concrete media is visually more active, fun, and motivating of learning. The results of interviews with several students found that students felt they had many opportunities to explore while unguided in the learning process. In addition, students also feel that students become more productive and careful in their learning. Students look enthusiastic during the learning process because they provide hands-on experience to form or develop knowledge well. This is consistent with the statement by Febriyanti, Nym, and Syahruddin (2014), which states that using real objects as a medium will make learning more meaningful and can increase student motivation in learning to achieve optimal learning outcomes. The results of this study are in line with research conducted by Ardana, Suniasih, and Ganing (2014), which shows an increase in the average presentation of science learning outcomes due to the application of explicit instructional learning models assisted by concrete media. Besides, other research that is in line with the results of this was conducted by Widiana, Murda, and Margunayasa (2015) and states that the Jigsaw 1 type of cooperative learning model, with the help of concrete media, has a positive effect on student science learning outcomes compared with conventional learning models. The results of research conducted by Hadiyati and Wijayanti (2017) stated that there was an increase in student learning outcomes after the application of concrete objects in the learning process. This means that the use of concrete media in learning has a positive influence.

The implication in this study is that the selection of appropriate learning activities can influence the achievement of students' factual knowledge. Factual knowledge of students can be optimally achieved if learning activities can encourage and activate students in participating in learning, one way of which is learning activities that can increase student curiosity. Learning media assisted learning activities are one of the innovative learning methods that can overcome the limitations of media in observing. This research proves that learning activities that are assisted by concrete media are well applied in learning as an effort to increase students' factual knowledge because that should not be ignored (Susanti et al., 2014; Yeh \& Park, 2015).

In learning activities, students get a direct experience from a model or tangible objects of an object. Students can manipulate these objects, and it is hoped that the results of the learning experience can be more meaningful to students, thereby developing an attitude of curiosity and developing sincerity and accuracy in seeking information through the five senses.

Based on the explanation of differences in students' factual knowledge between students who learn by learning activities to observe assisted with concrete media and students who learn by learning activities to observe unassisted by concrete media, several research results support the implementation of learning activities to observe assisted with concrete media. Groups of students who take part in learning activities with observing learning activities assisted by concrete media have higher factual knowledge compared with groups of students who take part in learning activities observing unassisted by concrete media. Therefore, there are significant differences in the abilities of students' factual knowledge between groups of students who study using concrete learning-assisted learning activities and groups of students who learn to use observational learning activities rather than concrete media-assisted themes in grade IV elementary schools in the Buleleng Regency 2016/2017 academic year.

\section{Conclusion}

Based on the results of data analysis, it can be concluded that there is a significant difference in the factual knowledge of groups of students who are learning by learning activities to observe assisted with concrete media and groups of students who are taught by using learning activities that are not assisted by concrete media in the fourth grade of elementary schools in the Buleleng Regency 2016/2017 academic year. From the post-test score, it can be seen that the average score of factual knowledge of the experimental group is greater than the control group. This means that the average score of factual knowledge of the experimental group using observational learning activities assisted by concrete media is better than the control group taught using learning without using observing activities aided by concrete media. Thus, it can be concluded that observing learning activities assisted 
by concrete media has a significant effect on the factual knowledge of fourth-grade elementary schools in the Buleleng Regency 2016/2017 academic year.

\section{References}

Antara, I. W. A., \& Renda, N. T. (2016). Analysis of the planning gap and implementation of 2013 curriculum learning in Kaliuntu 4 primary school. Journal of Education and Teaching, 49(2), 56. Available at: https://doi.org/10.23887/jppundiksha.v49i2.9010.

Ardana, P. W., Suniasih, N. W., \& Ganing, N. N. (2014). The application of the explicit instruction learning model is assisted by concrete media to improve the science learning outcomes of Grade VI students of SDN 17 Dangin Puri, Denpasar. The pulpit of the PGSD University of Education Ganesha, 2(1). Available at: https://doi.org/10.23887/jjpgsd.v2i 1.3744.

Asrizal, A., Amran, A., Ananda, A., Festiyed, F., \& Sumarmin, R. (2018). The development of integrated science instructional materials to improve students' digital literacy in scientific approach. Indonesian Natural Sciences Education Journal, 7(4), 442-450. Available at: https://doi.org/10.15294/jpii.v7i4.13613.

Astiti, N. M. L., Suniasih, N. W., \& Wiarta, I. W. (2015). Application of a scientific approach based on portfolio assessment to improve learning outcomes of mathematical knowledge and factual knowledge on the theme of my aspirations for fourth grade students at SD Negeri 3 Peguyangan. The pulpit of the PGSD University of Education Ganesha, 3(1). Available at: https://doi.org/http://dx.doi.org/10.23887/jjpgsd.v3i1.5099.

Cannady, M. A., Vincent-Ruz, P., Chung, J. M., \& Schunn, C. D. (2019). Scientific sensemaking supports science content learning across disciplines and instructional contexts. Contemporary Educational Psychology, 59, 101802. Available at: https://doi.org/10.1016/j.cedpsych.2019.101802.

Castela, A., Da Fonseca, B. S., Duarte, R., Neves, R., \& Montemor, M. (2014). Influence of unsupported concrete media in corrosion assessment for steel reinforcing concrete by electrochemical impedance spectroscopy. Electrochimica Acta, 124, 52-60. Available at: https://doi.org/10.1016/j.electacta.2013.11.157.

Darmadi, L. P., Sulastri, M., \& Rai, N. W. (2013). The effect of heroic leadership team student strategy assisted by concrete media on the learning outcomes of Natural Sciences in cluster 1 of Busungbiu Sub-district. The pulpit of the PGSD University of Education Ganesha, 1(1).

Dirk, D. B., Deprez, J., Van Dooren, W., Roelens, M., \& Verschaffel, L. (2011). Abstract or concrete examples in learning mathematics? A replication and elaboration of Kaminski, Sloutsky, and Heckler's study. Journal for Research in Mathematics Education, 42(2), $109-126$. Available at: https://doi.org/10.5951/jresematheduc.42.2.0109.

Dwipayanti, N. M. A., Sudhita, I. W. R., \& Parmiti, D. P. (2013). The effect of the ADDIE learning model is assisted by concrete media on the learning outcomes of the fifth grade students of SD state 1 General.The pulpit of PGSD University of Education Ganesha, 1(1). Retrieved from: https://ejournal.undiksha.ac.id/index.php/JJPGSD/article/view/1272/1135.

Esposito, A. G., \& Bauer, P. J. (2017). Going beyond the lesson: Self-generating new factual knowledge in the classroom. Journal of Experimental Child Psychology, 153, 110-125. Available at: https://doi.org/10.1016/j.jecp.2016.09.003.

Febriyanti, E. A. W., Nym, J. I., \& Syahruddin, H. (2014). Pengaruh model pembelajaran two stay two stray berbantuan media video terhadap hasil belajar IPS. Journal of PGSD Pulpit Education University of Ganesha, 2(1). Available at: https://doi.org/10.23887/jp2.v1i2.19333.

Fischer, B. C., Rotter, S., Schubert, J., Marx-Stoelting, P., \& Solecki, R. (2020). Recommendations for international harmonization, implementation, and further development of suitable scientific approaches regarding the assessment of mixture effects. Food and Chemical Toxicology, 141(4), 111388. Available at: https://doi.org/10.1016/j.fct.2020.111388.

Hadiyati, N., \& Wijayanti, A. (2017). The effectiveness of the experimental method aided by concrete media objects on the learning outcomes of the fifth grade elementary school students. JIPVA Journal of Veterans Science Education, 1(1), 24. Available at: https://doi.org/10.31331/jipva.v1i1.513.

Hernawati, D., Amin, M., Irawati, M., Indriwati, S., \& Omar, N. (2018). The effectiveness of scientific approach using encyclopedia as learning materials in improving students' science process skills in science. Indonesian Natural Sciences Education Journal, 7(3), 266272. Available at: https://doi.org/10.15294/jpii.v7i3.14459.

Jampel, I. N., \& Puspita, K. R. (2017). Improvement of primary school student learning outcomes through audiovisual assisted learning activities. International Journal of Elementary Education, 1(3), 197-205.

Jayanta, I. N. L., Suryantari, K. D., \& Sumantri, M. (2017). An analysis of discrepancy between the lesson plan and the implementation of curriculum 2013 in teaching and learning process in SD Negeri 4 Kaliuntu. Journal of Education Research and Evaluation, 1(2), 7381. Available at: https://doi.org/10.23887/jere.v1i2.9839.

Kapler, I. V., Weston, T., \& Wiseheart, M. (2015). Spacing in a simulated undergraduate classroom: Long-term benefits for factual and higher-level learning. Learning and Instruction, 36, 38-45. Available at: https://doi.org/10.1016/j.learninstruc.2014.1 1.001.

Moreira, I. X., Pereira, S., \& Gusmão, H. F. (2018). The influence of concrete instructional media on learning achievement. ISCE: Journal of Innovative Studies on Character and Education, 2(1), 104-114.

Retnawati, H., Hadi, S., \& Nugraha, A. C. (2016). Vocational high school teachers' difficulties in implementing the assessment in curriculum 2013 in Yogyakarta Province of Indonesia. International Journal of Instruction, 9(1), 33-48. Available at: https://doi.org/10.12973/iji.2016.914a.

Santiani, N. W., Sudana, D. N., \& Tastra, I. D. K. (2017). The effect of PBL models assisted by concrete media on the learning outcomes of science students in grade V elementary school. The pulpit of the PGSD University of Education Ganesha, 5(2). Available at: https://doi.org/http://dx.doi.org/10.23887/jjpgsd.v5i2.10826.

Schürmann, K., Ernst, A., Schumann, D., \& Hake, J. F. (2019). Transformation of energy systems as common projects: Integration of different scientific approaches to address real-world challenges. Energy Procedia, 158, 3534-3540. Available at: https://doi.org/10.1016/j.egypro.2019.01.915.

Stull, A. T., Barrett, T., \& Hegarty, M. (2013). Usability of concrete and virtual models in chemistry instruction. Computers in Human Behavior, 29(6), 2546-2556. Available at: https://doi.org/10.1016/j.chb.2013.06.012.

Suarjana, I. M., Riastini, N. P. N., \& Pustika, I. G. N. Y. (2017). Application of concrete contextual assisted by concrete media to improve learning activities and outcomes. International Journal of Elementary Education, 1(2), 103-1 14.

Susanti, K. A., Suadnyana, I. N., \& Zulaikha, S. (2014). The effect of snowball throwing model with the help of concrete media on the learning outcomes of IPA class V SD gugusi Gusti Ngurah Rai Denpasar. E-Journal of Ganesha University PGSD Pulpit, 2(1), 1-10. Available at: https://doi.org/http://dx.doi.org/10.23887/ijpgsd.v2i1.1924.

Syahroni, M., Dewi, N., \& Kasmui, K. (2016). The effect of using digimon (science digital module) with scientific approach at the visualizationof students' independence and learning results. Indonesian Natural Sciences Education Journal, 5(1), 116-122.

Triyuni, T. (2016). The influence of science learning set using scientific approach and problem solving model on learning outcomes of junior high school students in the subject of heat and temperature. Indonesian Natural Sciences Education Journal, 5(2), 177-185.

Usmeldi, U. (2016). The development of research-based physics learning model with scientific approach to develop students' scientific processing skill. Indonesian Natural Sciences Education Journal, 5(1), 134-139.

Wardani, N. K. P. K., Made, S. M. P., \& Mahadewi, L. P. P. (2016). The effect of snowball throwing model assisted by concrete object media on the learning outcomes of students in grade V. The pulpit of the PGSD University of Education Ganesha, 4(1). Available at: https://doi.org/http://dx.doi.org/10.23887/jipgsd.v4i 1.7453.

Widiana, I. N. A., Murda, I. N., \& Margunayasa, I. G. (2015). The influence of the Jigsaw 1 type of cooperative learning model with the help of concrete media on the learning outcomes of Class V science in elementary school XIV, Buleleng Sub-district in the $2014 / 2015$ academic year. The Pulpit of the PGSD University of Education Ganesha, 3(1), 5675. Available at: http://dx.doi.org/10.23887/jipgsd.v3i1.5675. 
Widyani, N. L. S., Suwatra, I. I. W., \& Widiana, I. W. (2017). The discrepancy of curriculum 2013 in teaching and learning process based on permendikbud No 65 of 2013 in SD laboratory Undiksha. Journal of Education Research and Evaluation, 1(2), 57-64. Available at: https://doi.org/10.23887/jere.v1i2.9840.

Yeh, D. D., \& Park, Y. S. (2015). Improving learning efficiency of factual knowledge in medical education. Journal of Surgical Education, $72(5)$, 882-889. Available at: https://doi.org/10.1016/j.jsurg.2015.03.012. 